\title{
The IMPACT OF Foreign SLOWDOWN ON THE U.S. ECONOMY: AN OPEN ECONOMY DSGE Perspective
}

\author{
Ozge Akinci, Gianluca Benigno, and Paolo Pesenti
}

\section{OVERVIEW}

- Global economic activity decelerated noticeably over the course of 2018, owing to various factors that affected major economies-including those of China and the euro area.

- At the same time, foreign growth projections for 2019 and 2020 were lowered, signaling potentially large headwinds for the U.S. economy.

\section{- The authors use a multi-country dynamic stochastic general equi- librium (DSGE) model to study the role of financial integration in the global transmission of demand shocks-examining the impact of economic spillovers to the United States from slow- downs originating in the euro area and China.}

- In a scenario with unrestricted policy space and rates above the zero lower bound, they find that the impact is sizable if the shock originates in Europe rather than in Asia, mainly because of greater financial integration between Europe and the United States.

- Policy space limitations in Europe amplify the effects of higher financial integration, and the economic contraction in the U.S. economy becomes more severe.
$\mathrm{O}$ ver the course of 2018, economic activity in major advanced foreign economies and emerging markets-including the euro area and China-decelerated noticeably. In parallel, foreign growth projections for 2019 and 2020 were revised down, signaling potentially large headwinds for the U.S. economy over the medium term. In this article we use a multi-country simulation model to quantify economic spillovers to the United States from a slowdown originating in the euro area. Next, we compare these results with spillovers from a slowdown originating in China. We find that spillovers to the U.S. economy from a slowdown in the euro area are sizable, mainly because of a lack of monetary policy space in the region along with greater financial integration between Europe and the United States. Standard trade-related spillovers to the United States from a slowdown in China, instead, are quantitatively limited.

The pace of global economic activity slowed down in the second half of 2018 owing to a variety of factors affecting the major economies, in particular, China and the euro area. Moreover, global growth forecasts for 2019 were revised down markedly. For example, the consensus forecast for annual euro-area GDP growth in 2019 dropped

Ozge Akinci is a senior economist, Gianluca Benigno an assistant vice president, and Paolo Pesenti a senior vice president at the Federal Reserve Bank of New York. Email:ozge.akinci@ny.frb.org; gianluca.benigno@ny.frb.org; paolo.pesenti@ny.frb.org.

The views expressed in this article are those of the authors and do not necessarily reflect the position of the Federal Reserve Bank of New York or the Federal Reserve System. To view the authors' disclosure statements, visit https://newyorkfed.org/research/epr/2020/ epr_2020_china-impact-of-slowdown_akinci. 
from 1.9 percent in mid-2018 to 1.1 percent at the beginning of 2019. Although U.S. domestic fundamentals were not projected to weaken at a similar pace, market participants promptly recognized that a global slowdown was bound to represent a significant source of macroeconomic headwinds for the U.S. economy. In this article, we provide a quantitative assessment of the extent to which these external developments could affect the U.S. macroeconomic outlook.

As a first pass to gauge the quantitative implications of foreign spillovers, we consider a number of model-based simulations adopting the SIGMA model, a multi-country dynamic stochastic general equilibrium (DSGE) model developed at the Federal Reserve Board for policy evaluation and scenario analysis. SIGMA offers a rich benchmark framework for the analysis of cross-border spillovers and trade interdependencies among countries. The model reflects current state of the art in terms of open economy modeling, and it serves our purpose of examining alternative scenarios in terms of different degrees of international financial markets integration among different economies and the possibility that economies might be constrained in terms of monetary policy space. ${ }^{1}$

Specifically, in our simulations we use a three-country version of SIGMA calibrated to a U.S. bloc, an advanced foreign economy (AFE) bloc, and an emerging market economy (EME) bloc. Given the three-bloc structure of the model economy, we assume that a slowdown in the GDP growth of the euro area or China leads to a decline in AFE or EME GDP growth by the same magnitude, respectively. Compared to the EME bloc, the AFE bloc is characterized by a relatively higher degree of trade and financial integration with respect to the United States. In the different regions covered in the simulations, monetary policies are assumed to follow inertial Taylor rules in which the nominal interest rate responds to the deviation of domestic inflation from the central bank's inflation target and to the deviation of output from potential output, subject to a zero-lower bound (ZLB) constraint.

To understand the interplay between limited policy space and higher financial integration within advanced economies, we proceed in two steps. We begin by considering a foreign slowdown (here, modeled as being due to a loss of consumer confidence that gives rise to a fall in consumption expenditure) when policy space in the AFE bloc is unrestricted and interest rates are above the ZLB. Next, we focus on the relevant case in which monetary policy in the AFE bloc is subject to the ZLB constraint. We consider two scenarios: In the first one, the global slowdown originates in the euro area (which is part of the AFE bloc); in the second one, the slowdown originates in China (which is part of the EME bloc). We find that the transmission of the China-led slowdown to the United States through trade and financial linkages is quantitatively limited, despite the fact that EMEs currently account for a large share of the global economy. ${ }^{2}$

The impact on the U.S. economy of a slowdown originating in the euro area is larger, mainly because of the greater financial integration within advanced economies. Intuitively, higher financial integration implies that the bulk of international adjustment occurs through a current account rebalancing: The contraction in total domestic demand in the AFE bloc generates larger capital outflows and more pronounced depreciation of the euro vis-à-vis the U.S. dollar. This translates into a bigger trade deficit in the United States and, hence, contributes to a more significant U.S. downturn compared with a similar slowdown originating in the EME bloc. When monetary policy space is limited in the AFE bloc, the effects of higher financial 
integration are amplified and the economic contraction in the U.S. economy becomes even more severe.

This article is organized as follows. Section 1 provides a brief overview of the model and characterizes the different regional blocs. Section 2 describes the recent performance of real GDP growth in major foreign economies. Section 3 outlines our quantitative experiments. Section 4 concludes.

\section{Overview of the Model}

The simulation exercises considered in this article are carried out by adopting SIGMA, the multi-country model used for international policy analysis at the Federal Reserve Board of Governors. Earlier vintages of the model are illustrated in detail in Erceg, Guerrieri, and Gust (2006), Erceg, Gust, and Lopez-Salido (2009), and Gust, Leduc, and Sheets (2009). The model adopts a medium-scale DSGE framework with financial frictions, where the latter are modeled à la Bernanke, Gertler, and Gilchrist (1999) by linking domestic credit spreads to entrepreneurs' net worth. The model includes numerous features that have been found to be critical for an empirically realistic response to a broad spectrum of domestic and international shocks (see, for example, Christiano, Eichenbaum, and Evans [2005], and Smets and Wouters [2007]): costs of changing the level of investment, habit persistence in consumption, and costs of adjusting trade flows. Final consumption and investment goods are produced using both domestically produced goods and imports. International financial markets are incomplete, in the sense that households' portfolio choices are restricted to borrowing or lending internationally a non-state contingent bond.

SIGMA features incomplete exchange rate pass-through from exchange rate changes to imported goods, consistent with the empirical evidence. This is because the model embeds demand curves with time-varying elasticities that induce strategic complementarity in price setting (see, for example, Kimball (1995) or Guerrieri, Gust, and Lopez-Salido (2010)). As a result, the desired markup in the model varies in response to fluctuations in the real exchange rate, which creates an incentive for firms to charge different prices in home and foreign markets (even under fully flexible prices). Prices and wages are set in staggered Calvostyle contracts, with prices set and invoiced in local currency in both domestic and foreign markets.

In each country bloc, monetary policy is assumed to follow an inertial Taylor rule in which the nominal interest rate responds to the deviation of domestic inflation from the central bank's inflation target and to the deviation of output from potential output. Nominal interest rates are subject to the ZLB constraint in the advanced economy bloc. There is an array of domestic and foreign shocks in the model, including shocks to permanent and temporary components of total factor productivity, markups, consumer confidence (implemented as shocks to the marginal utility of consumption of households), the foreign exchange risk premium, government expenditures, corporate spreads, and monetary policy.

The model is calibrated at a quarterly frequency. Most of the structural parameters are set at identical values for each of the three blocs, except for the parameters determining 
population size, the degree of trade openness, and the degree of financial integration. As discussed in Erceg, Guerrieri, and Gust (2006) in detail, the parameters governing the degree of openness are chosen such that U.S. imports are about 14 percent of GDP, and 55 percent of U.S. trade is with the EMEs in the simulations; both features are consistent with the data. The population levels are chosen such that the U.S. economy constitutes about 20 percent of world output, while the other advanced economies constitute 28 percent of world output. ${ }^{3}$

The model features incomplete international financial markets. Households in the AFE and EME blocs have access to a non-state contingent international bond, $B_{F t}$, issued by the U.S. private sector and denominated in the U.S. currency. From the perspective of a generic economy, we assume that its households pay a cost when adjusting their holding of the foreign bond. By combining the log-linear version of the intertemporal Euler equations in the United States and the $j=A F E, E M E$ countries, we obtain the modified uncovered interest parity equation, which is standard in incomplete market models:

$$
e_{t}^{U S-j}=E_{t} e_{t+1}^{U S-j}+R_{t}^{n j}-R_{t}^{n}-\nu_{F}^{j} b_{F t}^{j}
$$

where $\nu_{F}^{j}$ captures the extent of financial markets' imperfection, since it governs the degree of the portfolio rebalancing cost paid by the households in region $\mathrm{j}$. We assume that this cost depends on the ratio of economy-wide holdings of net foreign assets to nominal output, denoted by $b_{F t}$ in the model economy. The variable $e_{t}^{U S-j}$ denotes the bilateral nominal exchange rate between the United States and country $j$ (that is, the price of a dollar in terms of country j's currency), $R_{t}^{n}$ is the nominal policy rate in the U.S. economy, and and $R_{t}^{n j}$ is the nominal policy rate in country $j$.

Differently from Erceg, Guerrieri, and Gust (2006), we assume that the elasticity of the exchange rate with respect to the net foreign asset position in each bloc, $\nu_{F}^{j}$, differs across countries, so that we can capture different degrees of financial integration of the AFEs and the EMEs compared with the United States. In particular, we set the coefficient $\nu_{F}^{A F E}$ to a very small number to reflect the fact that financial frictions in borrowing or lending between the AFEs and the United States are very limited and financial markets are well integrated. Instead, this coefficient is set to a non-negligible constant for the EMEs to capture various possible international financial frictions between the U.S. economy and the EMEs that are not explicitly modeled in our quantitative framework.

\section{The Recent Global Slowdown: Stylized Facts}

As shown in Chart 1, foreign GDP growth decelerated in 2018, led mainly by a slowdown in the advanced foreign economies, after strong growth in 2017. Consensus growth forecasts for 2019 in both AFEs and EMEs were markedly revised down as well. As of the summer of 2019, advanced foreign economies are projected to slow down further in 2019, compared with the corresponding consensus forecast for 2019 at the beginning of 2018. Similarly, emerging economies are projected to slow down from a pace of around 4 percent to around 3.7 percent. 
CHART 1

Foreign GDP Growth

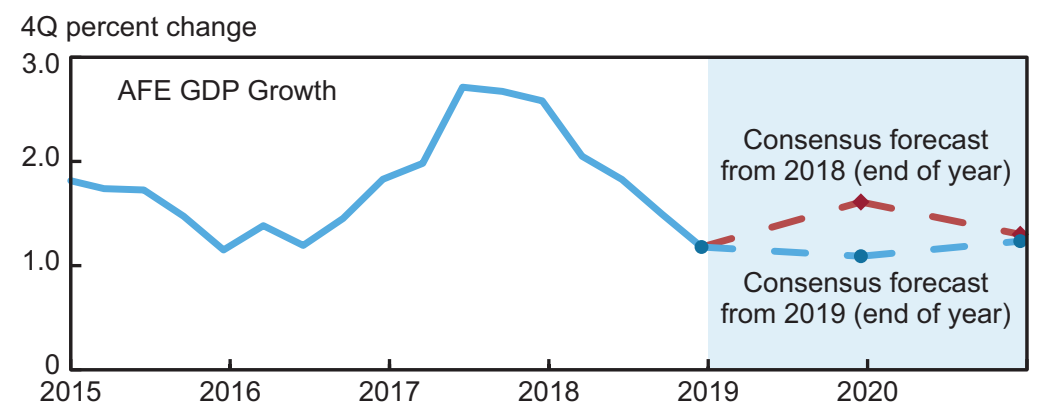

$4 Q$ percent change

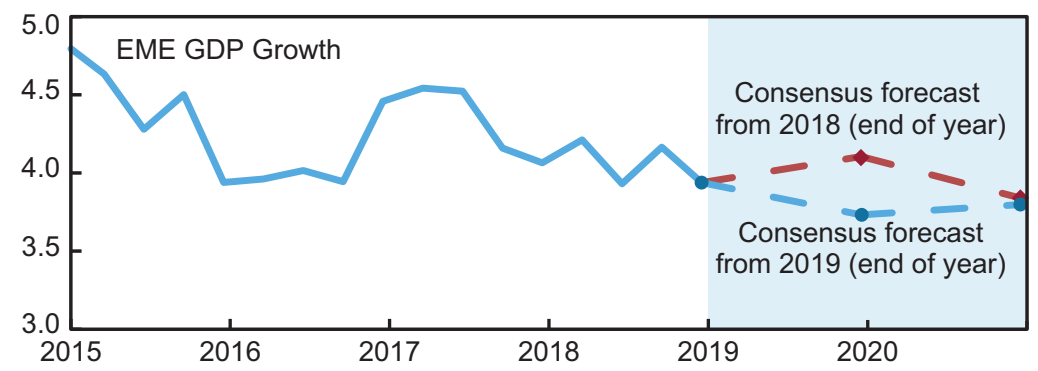

Sources: Consensus Forecasts, Consensus Economics Inc.; Haver Analytics.

For reference purposes, these economies were expected to continue to grow just above 4 percent in 2019 based on projections elaborated in early 2018.

Focusing on individual countries, as shown in Table 1, euro-area GDP growth slowed down from 2.7 percent (year-over-year) in 2017 to 1.8 percent (year-over-year) in 2018. Moreover, consensus forecasts for euro-area GDP growth in 2019 were marked down from 1.9 percent (as of March 2018) to 1.1 percent, while forecast revisions for 2020 were more limited. EME growth forecasts were also revised down for the majority of the countries, China included. These recent revisions for 2019 and 2020, relative to the forecasts produced around the first quarter of 2018, represent the quantitative underpinnings and the motivation for the experiments we consider in the next section.

\section{Model-Based Simulation Results}

This section presents our simulation results. We start by illustrating the effects on the U.S. economic outlook of a decline in foreign demand, when policy space in the AFE bloc is unrestricted. The objective here is to understand the role of higher financial integration for the transmission of foreign shocks to the U.S. economy. We next consider a foreign slowdown when policy space in the AFE bloc is restricted. 
TABLE 1

Annual GDP Growth in Selected Countries

2019

2020

20172018 Consensus Mar-18 Consensus Apr-19 Consensus Jan-19 Consensus Apr-19

\begin{tabular}{lcccccc}
\hline Euro Area & 2.7 & 1.8 & 1.9 & 1.1 & 1.4 & 1.3 \\
Japan & 1.9 & 0.8 & 1.1 & 0.6 & 0.4 & 1.6 \\
U.K. & 1.9 & 1.4 & 1.5 & 1.3 & 1.5 & 1.7 \\
Canada & 3.0 & 1.8 & 1.9 & 1.5 & 6.1 & 6.1 \\
China & 6.8 & 6.6 & 6.3 & 6.2 & 2.1 & 2.0 \\
Taiwan & 3.1 & 2.6 & 2.4 & 2.0 & 2.4 & 1.8 \\
Korea & 3.2 & 2.7 & 2.8 & 2.4 & 1.9 & 2.6 \\
Mexico & 2.4 & 2.0 & 2.2 & 1.6 & 2.6 & 3.8 \\
Brazil & 1.1 & 1.1 & 2.9 & 1.9 & 3.8 & 1.2 \\
\hline EMEs & 4.3 & 4.1 & 4.1 & 1.1 & 1.3 & \\
\hline AFEs & 2.3 & 1.5 & 1.6 & & 3.7 & \\
\hline
\end{tabular}

Sources: Country GDP data: Instituto Brasileiro de Geografia e Estatistica, Statistics Canada, National Bureau of Statistics (CHN), Statistical Office of the European Communities, Business Office of Japan, Bank of Korea, INEGI (MX), Directorate-General of Budget, Accounting, and Statistics (TA), Office for National Statistics (UK); consensus forecasts are from Consensus Economics.

\subsection{Effects of Slower Foreign Growth on the U.S. Economy}

We consider two scenarios regarding the sources of slowdown in the global economy. In the first scenario, we examine a global slowdown that originates in the euro area and propagates to the whole AFE bloc, and we trace its spillovers to the U.S. economy and EMEs through standard trade linkages. Our second scenario entails a global slowdown that originates in China and affects symmetrically the other emerging market economies included in the EME bloc, before getting transmitted to the United States and AFE blocs. Under each scenario we consider a consumer confidence shock (defined as a shock to the marginal utility of consumption of households) that leads to a 1 percent decline in AFE or EME private consumption on impact.

As is briefly explained in Section 2, in the model economy, the United States is financially more integrated with the AFE countries than with the EME bloc. This happens because there are various possible international financial frictions between the U.S. economy and the EMEs, which are captured by deviations from the uncovered interest parity condition that are linked to the foreign asset position of the country in the model economy (that is, EMEs face a non-negligible and time-varying risk premium in their access to international financial markets, and this premium negatively co-moves with the net foreign asset position of the country). 
CHART 2

Lower Advanced Foreign Economy or Emerging Market Economy Demand (No-ZLB Case)

Europe-led slowdown and ZLB in Europe
China-led slowdown and ZLB in Europe

United States

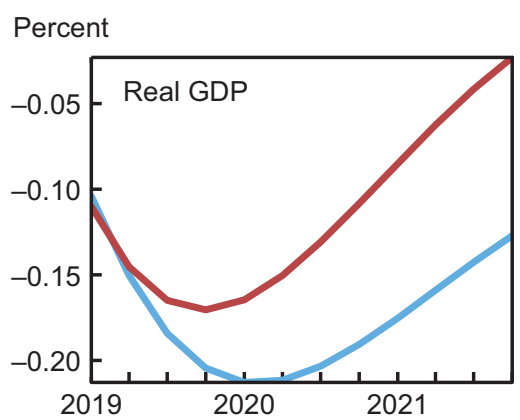

Percent

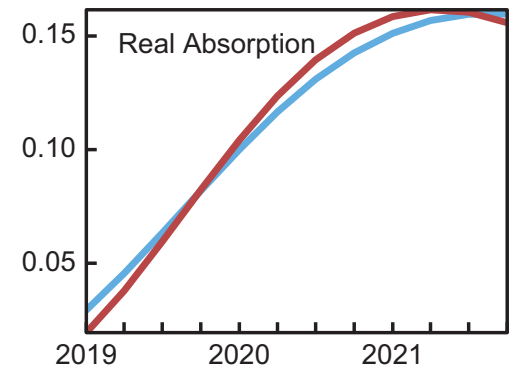

Percentage point

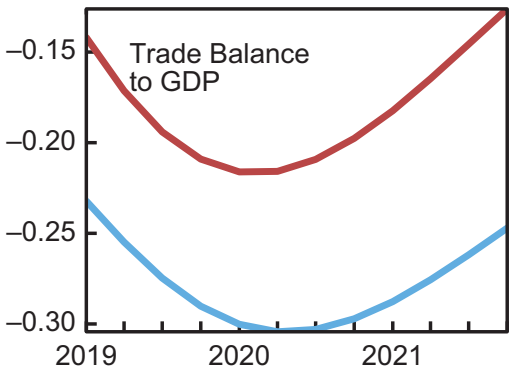

Annual percentage point

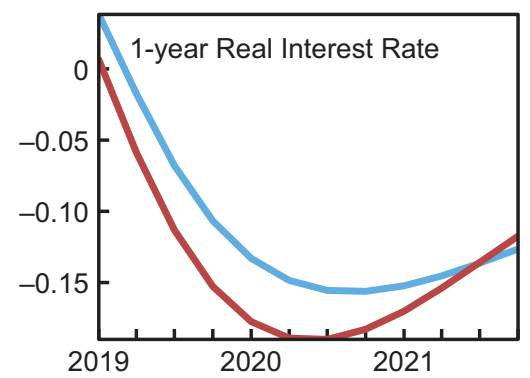

Annual percent

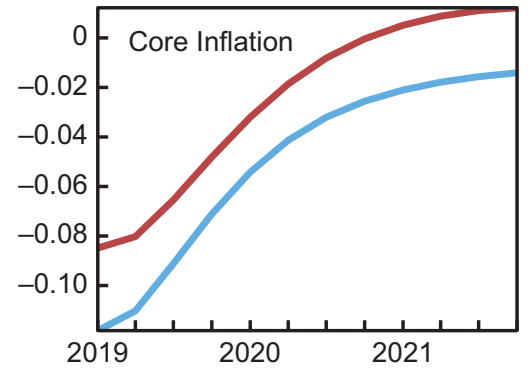

Percent

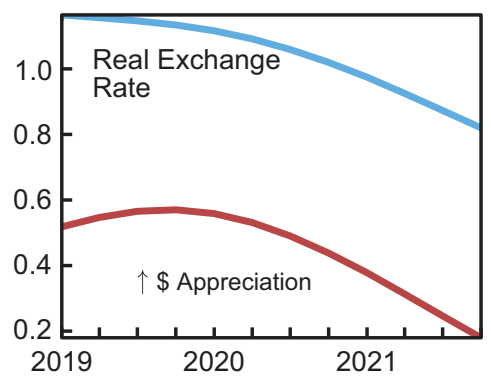

(CHART 2, CONTINUED ON PAGE 105)

The effects of the foreign slowdown on the U.S. economy and other foreign economies are shown in Chart 2. Blue lines correspond to the euro-area-led slowdown when policy rates in the AFE bloc are unrestricted. A shock is contractionary for the AFEs, leading to capital outflows from these countries to the United States and the EMEs, as reflected by their respective trade balance-to-output ratios shown in the chart. The trade balance improves in the AFE bloc and deteriorates in the United States and the EMEs. Capital outflows are associated with the 
Chart 2 (Continued)

Europe-led global slowdown

- China-led global slowdown

AFE

Percent

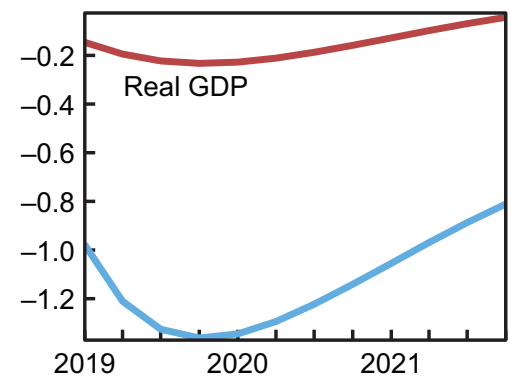

Percent

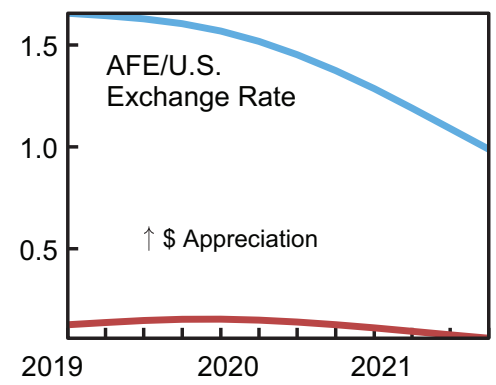

Percentage point

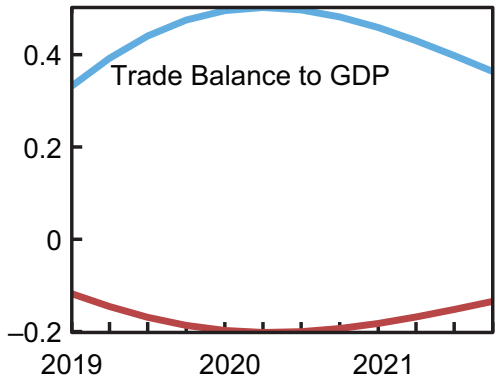

EME

\section{Percent}

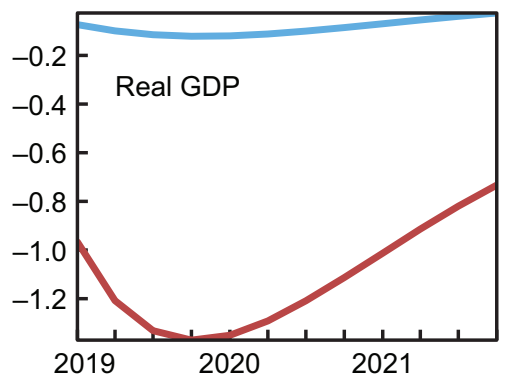

Percent

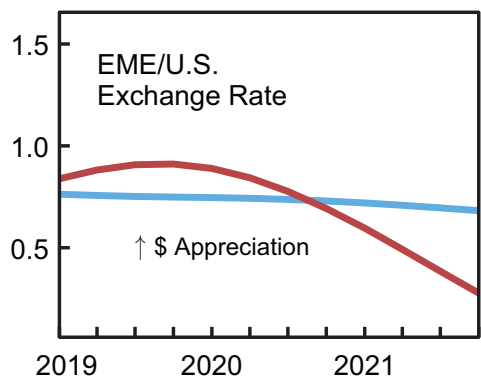

Percentage point

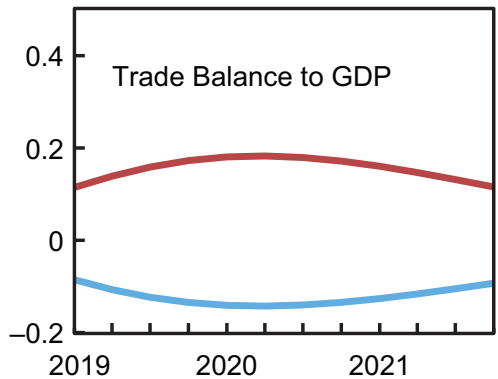

Source: Authors' calculations.

Notes: In the first six panels, the blue line (red line) shows the effects on the U.S. economy of a 1 percent decline in AFE (EME) consumption on impact when nominal interest rates are unconstrained. In the next six panels, the blue line (red line) shows the effects on the AFEs (the left column) and on the EMEs (the right column) of a 1 percent decline in AFE (EME) consumption on impact when nominal interest rates are unconstrained. 
depreciation of the AFE currency vis-à-vis the U.S. dollar and EME currencies. Despite the fact that the weaker AFE currencies boost world demand for their firms' exports, real GDP in the AFEs declines on impact and continues to deteriorate through mid-2020. Lower total foreign demand (note that the AFE shock is contractionary for the EMEs as well) and a stronger U.S. dollar cause U.S. net exports to fall. U.S. real interest rates rise for a very short period of time before falling persistently below the steady-state level, leading to a slight increase in U.S. domestic absorption. On net, U.S. real GDP decreases by about 0.25 percent throughout mid-2020. Core inflation in the United States falls about 0.15 percentage point due to a combination of lower economic activity in the United States and lower import prices (owing to appreciation of the dollar).

Our second scenario, which entails a steady slowdown in China, affects the U.S. economy through similar channels, but the overall size of spillovers is much smaller. The effects of the China-led EME slowdown on the United States are shown in Chart 2, with red lines for the case of unrestricted policy rates abroad. The shock is contractionary for the EMEs, leading to capital outflows from these countries to the United States, but as reflected in the smaller improvement in the trade balance-to-output ratios for the EMEs, capital outflows from EMEs are smaller under this scenario. As a result, the U.S. dollar appreciates less vis-à-vis the EME currencies, leading to a smaller contraction in U.S. net exports and GDP. Note that foreign demand decreases by a similar magnitude under both scenarios. However, in response to falling foreign demand and slower growth, the expenditure-switching effects on the U.S. economy are much smaller under this scenario. This is because U.S. goods are now less expensive from the vantage point of the foreign economies, reflecting the relatively moderate appreciation in the U.S. dollar. U.S. real interest rates fall, as in the previous scenario, and U.S. domestic absorption increases slightly. Note that domestic absorption improves less under this scenario owing to smaller decreases in import prices. For similar reasons, core inflation in the United States falls by less under this scenario compared with the one in which global slowdown originates in the euro area.

Overall, the impact of the shock on the United States is more pronounced under the scenario in which the foreign demand shock originates in the euro area compared with the scenario in which the shock originates in China. A key factor contributing to the stronger negative spillover is the fact that the U.S. economy is financially more integrated with the AFE countries than with the EME bloc.

\subsection{Spillovers and Availability of Policy Space Abroad}

Other things equal, the magnitude of the spillovers is crucially affected by the availability of policy space abroad, as summarized in Chart 3. In this section, we consider what happens when nominal interest rates are subject to the ZLB constraint in the AFE bloc (which is a more realistic case to consider given the fact that there is limited policy space in several advanced foreign economies). As before, the blue lines in the chart depict the global impact of the euro-area-led slowdown. Different from above, our simulation results now explicitly consider situations in which AFE policy rates are constrained by the ZLB. In the same chart, red lines plot the simulation results for the China-led EME slowdown under the assumption that the monetary authorities in the AFE countries are unable to cut their policy rates further down 
CHART 3

Lower Advanced Foreign Economy or Emerging Market Demand (ZLB Case)

Europe-led slowdown and ZLB in Europe

China-led slowdown and ZLB in Europe

United States

Percent

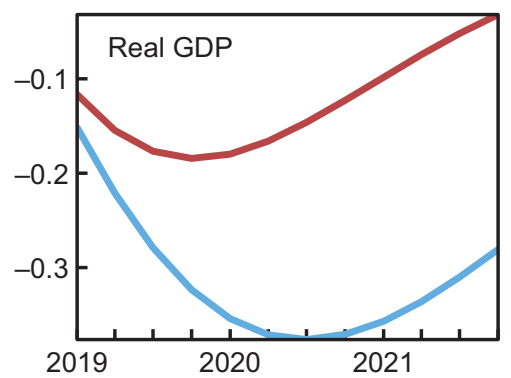

Percent

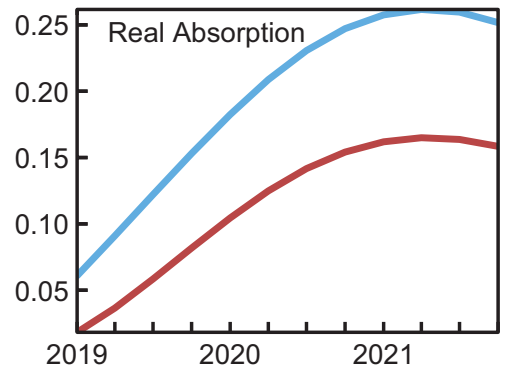

Percentage point

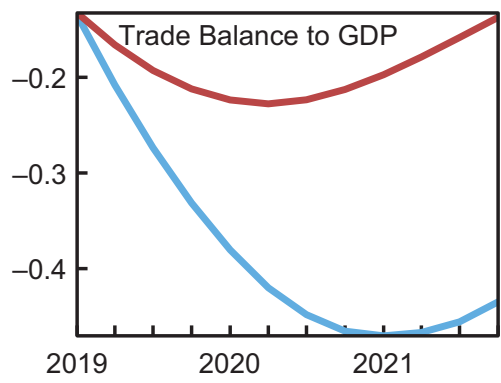

Annual percentage point

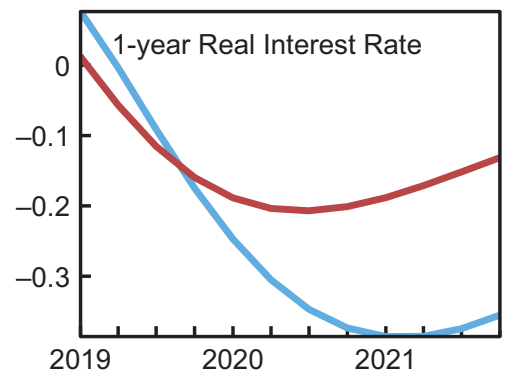

Annual percent

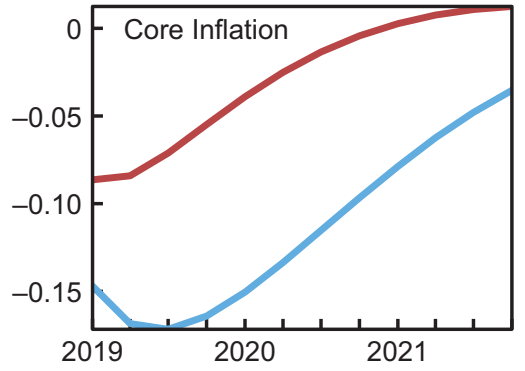

Percent

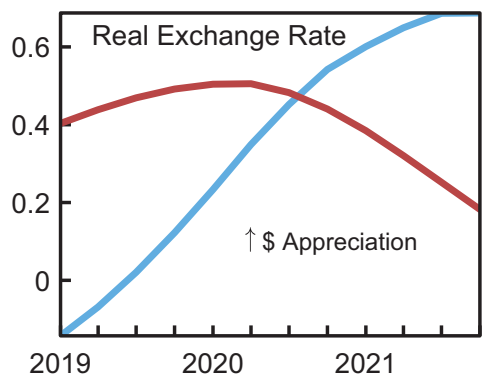

(CHART 3, CONTINUED ON PAGE 108)

below the baseline path. Under each scenario, we continue to consider a consumer confidence shock that leads on impact to a 1 percent decline in AFE or EME private consumption if nominal rates were not constrained.

Reduced policy space abroad has key implications for the transmission of the global slowdown to the U.S. economy through standard trade linkages, to the extent that the shock originates in the euro area. This shock is now severely contractionary in the AFEs, since the policy rate cannot 
Chart 3 (CONTINued)

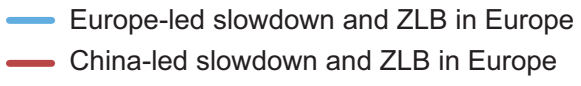

AFE

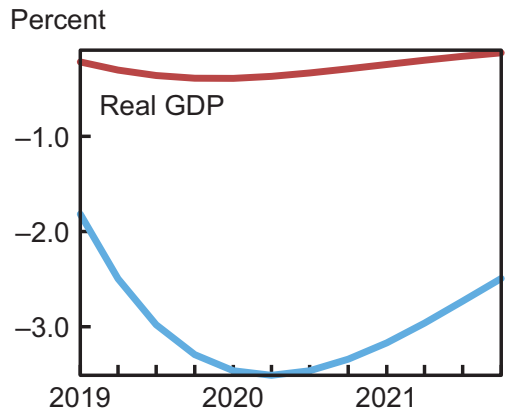

Percent

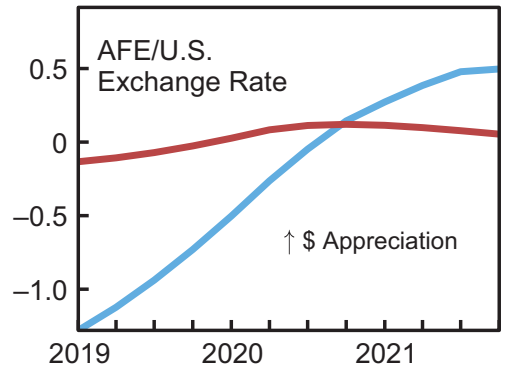

Percent

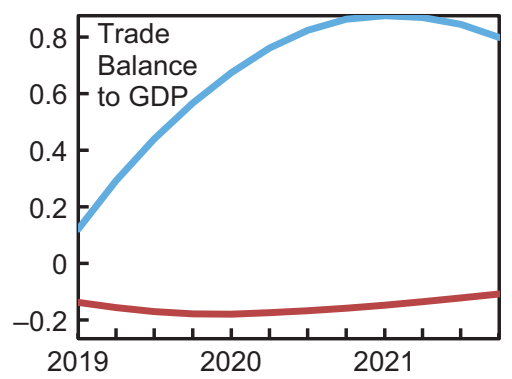

EME

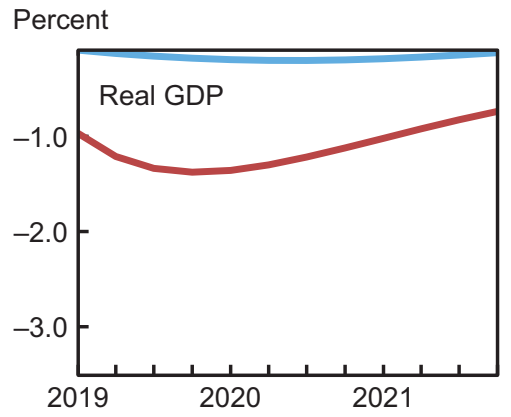

Percent

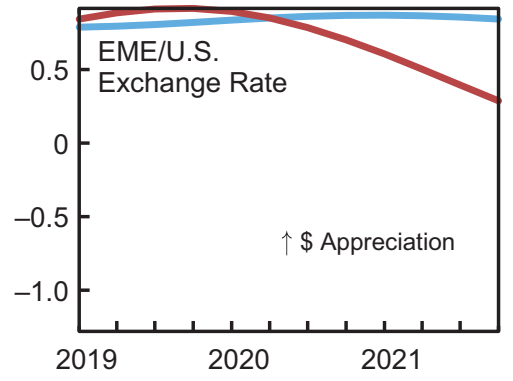

Percentage point

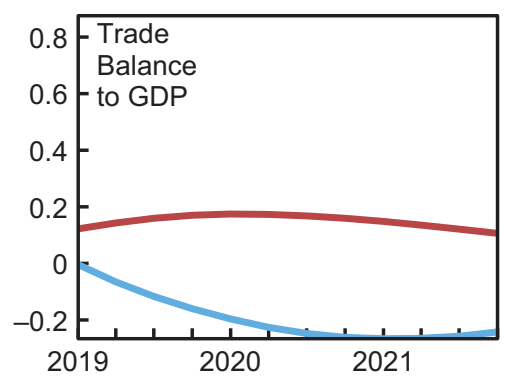

Source: Authors' calculations.

Notes: In the first six panels, the blue line (red line) shows the effects on the U.S. economy of a shock equivalent to a 1 percent decline in AFE (EME) consumption on impact if nominal rates were unconstrained. In this simulation we assume that AFE policy rates are constrained by the ZLB. In the next six panels, the blue line (red line) shows the effects on the AFEs (the left column) and on the EMEs (the right column) of a shock equivalent to a 1 percent decline in AFE (EME) consumption on impact if nominal rates were unconstrained. In this simulation we assume that AFE policy rates are constrained by the ZLB. 
be cut below the effective lower bound to stimulate economic activity. As a result, net capital outflows are almost twice as large as the net outflows obtained under the unconstrained policy case (similarly, we have a larger improvement in the AFE trade balance-to-output ratio). A fall in AFE GDP causes the level of U.S. GDP to decrease through lower foreign demand (note that the AFE shock is contractionary for the EMEs as well). Unlike in the unrestricted monetary policy case, the real broad dollar slightly depreciates on impact, reflecting the greater divergence between the monetary policy rates in the United States (which can be reduced to stimulate the economy) and the AFEs (whose policy rates are stuck at the ZLB). In fact, AFE currencies vis-àvis the U.S. dollar appreciate by around 1 percent on impact, while they depreciated around 1.5 percent in the unrestricted policy case. Conditional to a restricted AFE policy rate, the combination of an initial depreciation in the U.S. dollar and a much shallower path for the appreciation of the dollar thereafter tends to mitigate the drop in U.S. output. U.S. real interest rates now decline more, providing more stimulus for U.S. private absorption and aggregate demand. Nonetheless, the expenditure-reducing channel of lower foreign demand dominates, and U.S. real GDP decreases around 0.4 percent by mid-2020. U.S. core inflation decreases a bit more because of much lower economic activity, despite the fact that U.S. import prices fall less.

As above, the China slowdown has a relatively muted impact on the U.S. economy through standard trade linkages. The impact of the initial shock on the foreign economies is somewhat amplified under the scenario of a China-led slowdown owing to limited policy space in the AFEs. Yet, the overall size and the channels of spillovers to the United States from a slowdown in foreign economies are not very dissimilar across policy scenarios.

\section{Conclusion}

We have studied the impact of a foreign slowdown on the U.S. economy through the lens of a multi-country DSGE model developed at the Federal Reserve Board. In order to assess the role of financial integration in the global transmission of shocks, we have first considered a foreign slowdown scenario when policy space in the AFE bloc is unrestricted and interest rates are above the ZLB. We have considered two sources of global slowdown: In the first one, the source of slowdown originates in the euro area, which is financially more integrated with the U.S. economy; in the second one, a slowdown originates in China, which is less integrated with the U.S. economy. We assume that foreign demand decreases by a similar magnitude under both scenarios. Our simulations suggest that the impact on the United States of a global slowdown is stronger if the shock originates in Europe rather than in Asia, an intuitive result in light of the greater financial integration that characterizes the transatlantic economy. Under higher financial integration, in fact, international adjustment occurs through a current account rebalancing: The contraction in domestic demand in the AFE bloc translates into a bigger trade deficit in the United States, thus contributing to a more significant U.S. downturn compared with the scenario depicting an equivalent slowdown in the EME bloc. We next considered a scenario analysis where policy space in the AFE bloc is restricted in order to assess the role of limited policy space in the advanced economies outside the United States. When policy space is limited, the effects of higher financial integration are amplified, and the economic contraction in the U.S. economy becomes more severe. 


\section{Notes}

1 As any model, SIGMA has limitations: here we emphasize that the model tends to understate the importance of financial amplification effects across countries because of its simplified international financial market structure. To allow for a more realistic treatment of key financial frictions, the simulations need to include exogenous financial shocks. Similarly, it does not fully capture the complexity of the trade interaction among countries in terms of global value chain and currency- invoicing in firms' price-setting behavior.

2 When measured in terms of purchasing parity power, the share of China's GDP in world GDP (19.18 percent) overtook that of the United States (15.01 percent) in 2014.

3 The calibration of the two-country version of the model is presented in Erceg, Guerrieri, and Gust (2006). 


\section{REFERENCES}

Bernanke, B. S., M. Gertler, and S. Gilchrist. 1999. “The Financial Accelerator in a Quantitative Business Cycle Framework.” In J. B. Taylor and M. Woodford, eds., НАndвоок оғ Масвоесоnомics, Vol. 1 1341-93. North Holland: Elsevier.

Christiano, L. J., M. Eichenbaum, and C. L. Evans. 2005. "Nominal Rigidities and the Dynamic Effects of a Shock to Monetary Policy.” Journal of Political Economy 113, no. 1: 1-45.

Erceg, C. J., L. Guerrieri, and C. Gust. 2006. "SIGMA: A New Open Economy Model for Policy Analysis." International Journal of Central Banking 2, no.1 (March): 1-50.

Erceg, C., C. Gust, and D. Lopez-Salido. 2009. "The Transmission of Domestic Shocks in Open Economies." In J. Gali and M. J. Gertler, eds., International Dimensions of Monetary Policy, 89-148. Cambridge, Mass.: NBER.

Guerrieri, L., C. Gust, and D. Lopez-Salido. 2010. "International Competition and Inflation: A New Keynesian Perspective.” American Economic Journal: Macroeconomics 2, No. 4 (October): 247-80.

Gust, C., S. Leduc, and N. Sheets. 2009. "The Adjustment of Global External Balances: Does Partial Exchange-Rate Pass-Through to Trade Prices Matter?” Journal of International Economics 79, no. 2 (November): $173-85$.

Kimball, M. S. 1995. "The Quantitative Analytics of the Basic Neomonetarist Model." Journal OF Money, Credit, and Banking 27, no. 4: 1241-77.

Smets, F. and R. Wouters. 2007. "Shocks and Frictions in US Business Cycles: A Bayesian DSGE Approach.” American Economic Review 97, no. 3 (June): 586-606. 


\section{ECONOMIC POLICYREVIEW}

The Economic Policy Review is published by the Research and Statistics Group of the Federal Reserve Bank of New York. The views expressed are those of the individual authors and do not necessarily reflect the position of the Federal Reserve Bank of New York or the Federal Reserve System.

Series Editor: Julian di Giovanni. Editorial Staff: Robert Powell, Trevor Delaney, Maureen Egan, Anna Snider, and Peter Stevens. Design Staff: Theresa Izzillo, Laura Gharrity, and Jessica Iannuzzi.

Economic Policy Review articles may be reproduced for educational or training purposes, provided they are reprinted in full; include credit to the author(s), the publication, and the Bank; and include the publication's disclaimer.

(C2020 The Federal Reserve Bank of New York

www.newyorkfed.org/research

Follow us on Twitter: @NYFedResearch 